\title{
Transparency in Lobbying as Perceived by Organisational Representatives in the Czech Republic
}

\section{Lucie Vnoučková, Milan Žák ${ }^{1}$}

\begin{abstract}
This paper focuses on transparency in lobbying as perceived by in sample organisations in the Czech Republic. The paper's aim is to study how lobbying and its impact on decision-making practices are perceived by organisational representatives and to empirically assess the perceived transparency of lobbying with a view to the potential introduction of lobbying regulations and their role in Czech democracy. Data for the study was gathered from a sample of business institutions in the Czech Republic. In total, 73 organisations/institutions took part in the survey. One respondent was questioned per organisation/institution. $90 \%$ of respondents perceive that transparent and regulated lobbying has a positive impact on democracy. Moreover, according to the respondents, lobbying facilitates more competent decision-making among politicians, brings more information into the decision-making process and makes the process more efficient. There has been a significant shift in the perception of lobbying over the past ten years in the Czech Republic. Regulations aimed at legitimizing lobbying are seen as having a positive impact on democracy.
\end{abstract}

Key words: Lobbying, transparency, democracy, stakeholders, regulation, perception

JEL Classification: D72, D82

Received: 22 May 2017 / Accepted: 9 October 2017 / Sent for Publication: 8 December 2017

\section{Introduction}

The impact of transparent lobbying on economic policy and democracy is often discussed. Current theory proposes that transparency in lobbying may contribute to the democratic environment and to the more efficient allocation of public funds. The impact of transparent lobbying on economic policy and democracy is discussed, mostly on the basis of theoretical reviews and conceptual models with marginal empirical evidence. Meanwhile, how the impact of lobbying on democracy is perceived has hardly been investigated at all. The relevancy of lobbying and its consequences are questioned. This paper therefore presents both up to date theory and theoretical concepts related to the impact of transparency in lobbying, and also an empirical study of how business respondents perceive the impact of (more or less) transparent lobbying on democracy.

\footnotetext{
${ }^{1}$ University of Economics and Management, Prague, Czech Republic, Nárožní 2600/9a, 15800 Praha 5, e-mail: lucie.vnouckova@vsem.cz; milan.zak@vsem.cz

@ 2017 by the authors; licensee Review of Economic Perspectives / Národohospodářský obzor, Masaryk University, Faculty of Economics and Administration, Brno, Czech Republic. This article is an open access article distributed under the terms and conditions of the Creative Commons Attribution 3.0 license, Attribution - Non Commercial - No Derivatives.
} 
Generally, transparency in lobbying reflects the level of disclosure, accuracy and comprehensibility of information (Laboutková and Vymětal, 2017). However, theoretical papers have revealed that transparent lobbying creates high costs for rule implementation and higher costs associated with the implementation of incentives for agents, which leads to the maximisation of the principal's interest rather than the agent's (Moe, 1984). Currently, stakeholders and lobbyists participate in the political process in many ways (Bennedsen and Feldmann, 2002); e.g. by testifying in congressional and administrative hearings, through formal and informal communication with policy makers and their staff, by presenting their views and information, drafting policy proposals and providing legal expertise, and by informing and mobilizing others on matters that may concern them (Schlozman and Tierney 1986). Thus, attention should be paid by control mechanism and public to all stakeholders, interest groups and lobbyists when examining the impacts of their actions' transparency on democracy. More transparent lobbying increases the attention paid to lobbying activity, and thus clearly affects its impacts.

Transparency in lobbying is one of the most important topics as regards the functioning of those countries' democratic systems. The post-communist European countries are still struggling with a lack of transparency and widespread corruption in various parts of the public sector (Pavlík, 2013; Transparency International, 2017). This paper therefore investigates transparency in lobbying and its perceived impact on democracy in the Czech Republic. Florini (2004) adds that transparency supports efficient and effective public decision-making and governance by building and providing a feedback loop enabling politicians, officials and the public to evaluate decisions and policies, and discuss and adjust them accordingly. Cotterrell (1999) specifies that transparency increases the availability of information that matters to citizens, the public's ability to participate in political decisions, and the openness and accountability of government to the public.

As Redoano (2010) states, the number of registered lobbies at the European Union (EU) level has rapidly increased in recent years. Moreover, Stubb (2008) states that there are currently between 15,000 and 20,000 lobbyists and around 2,500 lobbies in Brussels trying to influence EU policies. Research shows that these numbers are growing steadily and are numerically second only to Washington, DC. Based on the growing influence of interest groups on European policy, the European Commission introduced a lobbyists' register and a code of conduct as part of a wider transparency initiative (Redoano, 2010). However, to date no such register or code has been adopted in the Czech Republic. In 2005, a study by Donath-Burson-Marstellar (2005) reported that only $12 \%$ of respondents in post-communist countries perceived lobbying as a positive activity. The same percentage of respondents assessed lobbying as very important (37\% saw it as somewhat important), while $46 \%$ of respondents considered it somewhat unimportant and $12 \%$ very unimportant. On the other hand, according to MaGrath (2008) the percentage of companies in the Czech Republic that saw lobbying as important rose from 61 to $84 \%$ between 2001 and 2004. Those results seemed to present quite a confusing public impression of lobbying, and thus we decided to conduct new research into the perception of lobbying and its transparency, and its importance for democracy in the Czech Republic in 2017. Our study sheds light on the current view of lobbying and its transparency in the Czech business sector and thus can help us to formulate recommendations to 
improve the transparency of public decision-making processes and their perception in the business sector.

This paper focuses initially on transparency in lobbing and models of transparent lobbying in the theoretical literature; our empirical study is then used for verification of the theory. The data used in the empirical study was gathered from a sample of businesses located across all districts of the Czech Republic $(n=73)$. Representatives of these businesses were surveyed in spring 2017. The organisations were asked questions regarding their attitude towards lobbing, its transparency and what they perceived to be its impact on democracy. Our study evaluates the primary quantitative data using descriptive and two-dimensional statistics to analyse how the businesses perceive the influence of (transparent) lobbying on perceived democratic decision-making. The results show that our respondents perceive that transparent and regulated lobbying has a positive influence on democracy. Moreover, statistical tests show that there is a positive relationship between greater transparency in lobbying and more positive attitudes towards the democratic decision-making process and its efficiency.

The paper is structured as follows: we begin by presenting the relevant theory and a summary of the current state of knowledge as regards transparency in lobbying. We then introduces our empirical study and explain the methodology used. A presentation of the results of the study follows, rounded off with a discussion and conclusion in which we focus on the implications of this paper's findings.

\section{Theoretical Background}

As Fairbanks et al. (2007) state, successful democracy can be characterized by the existence of a public informed about its government's actions. Thus, government information has to be open and accessible to the public. A critical part of the success of a democratic government is having a public that is informed well enough to make appropriate decisions about who to select as their leaders. For this to happen, the public needs to have access to information about the government's actions and decision-making processes; in other words, the government's actions must be transparent. Over the past years and decades, there have been some drastic declines in public trust in governments related to i.e. normalization, velvet revolution (Putnam, 1995). Fairbanks et al. (2007) noted that these declines were the result of poor communication between policy-makers and the public, leading to the public feeling that they were poorly informed about their government's actions. Also Heise (1985) referred to poor communication between policy-makers and the public. To fix this situation by improving decision-makers' communication with the public, Heise (1985) proposed a model of communication in public administration which incorporates open and responsive communicative practices. Similarly, Laboutková and Žák (2016) formulated a simple relationship model involving three parties: interests, the decision maker and the outcomes.

According to Finel and Lord (1999), elements that affect the transparency of politicians and of government actions in democracies include a "free press, open government hearings, and the existence of nongovernmental organizations with an incentive to release objective information about the government" (Finel and Lord, 1999, p. 316). As Frost (2003) states, having a separate law governing the transparency of public policy opens 
up government, makes it more accountable, and prevents the loss of public trust in the government. This kind of law gives citizens public access to government information, with the exception of information that is secret or protected (Garnett, 1992; Frost, 2003).

To study this subject, various studies have been conducted in various environments that look at the role of transparent organizational practices in increasing trust. In all environments and areas, transparent practices have become more widespread in recent years (Fairbanks et al., 2007). Decision makers, scholars, practitioners and citizens have all realized that open and honest communication is essential to building, maintaining, and restoring relationships based on trust (Goodman, 2002). Increases in transparency have also been related to the reduction of corruption in corporations, public decision-making and government (Stoker and Rawlins, 2004; Fairbanks et al., 2007).

\section{Lobbying and Lobbying Transparency}

Lobbying is an activity that can influence the final shape of policies and markets, particularly in relation to the dominant politics of the redistribution process and process of democratization. Therefore, transparency in lobbying plays a crucial role in economic policy decision-making processes (Laboutková, Žák, 2016). For the purposes of this study, we define transparency based on Vishwanath and Kaufmann (1999) and Bellver and Kaufmann (2005) as the "increased flow of timely and reliable economic, social and political information, which is accessible to all relevant stakeholders". Transparent lobbying, based on this definition, should help to ensure the equal redistribution of public funds. Because of its redistributive effect, lobbying is often seen as a way of influencing policy decisions for the lobbyists' personal benefit.

In democratic societies, transparency and access to information may be considered a human right (Bellver and Kaufmann, 2005). Furthermore, Bellver and Kaufmann (2005) state that lobbying transparency increases efficiency in the allocation of resources. Beaumont (1999) finds that open administrative communication and procedures play a crucial part in achieving democratic government (even during economic transformation processes) and increase public confidence in politics and decision-makers. Another possible way of improving communication between decision-makers and the public is to foster a culture of transparent lobbying, because transparent lobbying activities open up professional/public practices to public scrutiny (Finel and Lord, 1999; Striton and Lodge, 2001; Bunting, 2004; Fairbanks et al., 2007).

McGrath (2008) states that lobbying is neither accepted nor understood in the Central and Eastern European [CEE] countries to the extent that it is in the older EU member states according to surveys of companies from 2001 to 2004 in the CEE nations. Many interest groups in the CEE countries are still learning how to lobby effectively and professionally. Pérez-Solórzano Borragán (2006) described civil society organizations operating in the CEE countries as dispersed, incoherent and uncooperative with poorly developed structures and skills insufficient to influence national or EU policy.

Lobbying is also seen as suspicious by many because they do not know what it is (Donath-Burson-Marstellar, 2005). Lobbying usually only receives widespread attention in the Czech Republic when it is discussed in the media as part of a scandal. When an incident is revealed, the public is misinformed, e.g. the director of Transparency International in the Czech Republic was reported as having said: "Nobody knows who these 
lobbyists are. They are the strangest people in Parliament" (Reynolds, 2005). Czech lobbying and politics are very tightly intertwined. Certain lobbyists have moved into government or vice versa (McGrath, 2008). Moreover, the precise lobbying techniques which are employed by various interest organizations in i.e. EU are missing in the Central and Eastern European states. Usually, both political parties and parliaments assume a very central role in the CEE states; usually greater than in more established executivedriven democracies, where other democratic mechanisms are used (Wiesenthal, 1996).

For example, the results of a previous study conducted in the Czech Republic by Donath-Burson-Marstellar (2005) on the same structure of respondents as the study we present in this paper show that $43 \%$ of respondents assessed lobbying as being somewhat important, while $58 \%$ of respondents believed lobbying to be unimportant.

The literature thus suggests that lobbying is still in its early stages in Central and Eastern European (EU) member states, but it has been growing and developing rapidly in recent years. Lobbying is increasingly perceived as a way of recognizing the value of participation in policy by government and public (Redoano, 2010; Laboutková and Vymětal, 2017). Moreover, the Central and Eastern European countries (especially the Czech Republic) are still in the process of opening their government up to external influence, after the fall of communism. The current rapid growth in support for transparency and lobbying may thus be seen to be even more significant in these countries than in more developed democracies (McGrath, 2008).

\section{Transparency and Regulation in Decision-making Processes}

Early transparency practices were based on the public information model of public relations, which advised decision-making bodies to openly share information about their practices with the public; if problems were found, then the decision-making body should accept responsibility and correct the problem (Grunig and Hunt, 1984). The current approach towards transparency emphasizes the importance of corporate social responsibility, recognizing the benefits of openness in the disclosure of corporate information (Sykes, 2002; Laboutková and Žák, 2016).

The business sector's political lobbying activity has frequently been successful at 'impacting' the state (Hellman et al., 2000). On the other hand, Frye (2002) states that the state-business relationship is a mutually beneficial exchange, in which political leaders gain advantages through their dealings with businesses. Previously, small and medium businesses had little weight and were relatively powerless in negotiating their political interests (McGrath, 2008). That began to change with the development of business associations, through which they could join together to promote their legislative and regulatory interests. Sullivan et al. (2006) also point out that coalitions of associations have also formed for the purposes of political lobbying (campaigns and individual meetings with politicians). Grødeland (2006), Sopóci (2001), and Kalninš (2005) all report that the decision-making processes in the Czech Republic and post-communist countries were previously in the hands of individuals with contacts: those who knew public officials personally and were willing to try to influence them. Even today, the Czech Republic has no statutory regulation of lobbying, only a voluntary code of ethics which applies to members of both Chambers of the Parliament and provides guidance as to how they should interact with interest groups and communicate with lobbyists (OECD, 
2006). It is still based on contacts within small group of people in the Czech Republic with a limited view outside the Republic. Furthermore, none of the CEE countries considers lobbying in Brussels a high priority (McGrath, 2008). Sevella (2006) states that the reason behind this is a lack of experience of the European environment and often a low awareness among CEE interest groups of the EU regulations' impact on their interests.

The study we present in this paper provides a new, detailed case study on the current perception of lobbying and its transparency in the Czech Republic among organisational representatives.

\section{Methods and Materials}

Our theoretical analysis uses a comparative method, while the empirical section of the paper is based on the synthesis of the knowledge acquired in our study. Our recommendations are based on the quantitative results of that study, which used questionnaire data collection techniques. The data was collected using a primary quantitative survey by means of a questionnaire. The questionnaire was completed on behalf of each organization contacted, by one chosen respondent; there was only one respondent per business. The data collection respected the legal requirements for ethical research (Personal Data Protection Act no. 101/2000 Coll.).

\section{Data sample}

Selected company representatives were contacted by e-mail. The electronic questionnaire responses were automatically recorded and the respondents' answers were precategorized (using the CAWI method). The questionnaire consisted of two sections; the first focused on lobbyists and the second on those they lobby. In total there were 10 questions on lobbying (covering lobbying in general, transparency of lobbying, transparency of lobbyists, the impact of lobbying on democracy, the transparency of the political environment, legislation regarding lobbying, relations to stakeholders, data availability, financing and regulations) and one identification question on the respondent's current job position. A semantic differential permitted the identification of nuances in the respondents' attitudes throughout the questionnaire. The respondents' reactions to target statements and their attitudes to the given matter were restricted by offering a set of several statements. The body of the questionnaire consisted of block questions with partial sub-questions to which respondents gave their answer using a 4-point scale from completely agree to completely disagree. In total, 73 respondents participated in the questionnaire survey. Overall the return rate on the questionnaire was low (8\%), because of the specific topic; potential respondents did not always have knowledge or experience of lobbying and thus could not answer. The representatives of the businesses and NGOs contacted were located across all districts of the Czech Republic and were contacted in spring (March - May) 2017. During that period no significant incident happened in the Czech political environment. On the other hand, the political scene changes constantly and so some relevant changes have taken place recently; for example, the Czech minister for human rights, equality and legislation is in the process of preparing draft measures to enhance the transparency of the legislative and decision-making 
process in relation to lobbying. However, that draft is not yet complete and has not yet been adopted.

The database of organisations (business and NGOs) asked to fill the survey was created based on their perception towards lobbying, its transparency and perceived impact on democracy. The snowball technique was used to gain contacts. The contacts were selected to be representative of organisations in the Czech economy in terms of their size, number of employees, type (profit/non-profit/public) and ownership, based on data provided by the Czech Statistical Office. The questionnaire responses themselves were anonymous, since a previous pilot study had revealed that respondents were unwilling to provide further information about their organisation. The representative of each organisation who filled in the questionnaire was fully employed by that organisation and participated in the organisation's decision-making processes (i.e. Held a managerial or other senior position). $56.2 \%$ of respondents were employed by businesses, $11 \%$ worked for non-profit organisations and $32.8 \%$ of them were self-employed or worked in public institutions.

\section{Data processing}

The first stage of processing the questionnaire results focused on the preparation of a data matrix. The data was described and subsequently coded and sorted according to the type of variables (qualitative, quantitative). During this phase, the data was also cleaned, and its quality was checked to uncover any extreme (eccentric) or deviating observations which could significantly influence the results of our analysis. An integral part of this stage included an analysis of any missing values. The last part of the data matrix involved transformation of the variables, which was necessary for several reasons - data testing and coding and identification of variables. When processing a multidimensional data file, the reason for this is to fulfil the conditions of a statistical tests.

The respondents' answers were categorized according to the identification questions which formed the first part of the questionnaire. Here, the measurement was based on closed questions with relevant literature. A semantic differential applied throughout the questionnaire permitted the identification of nuances in the respondents' attitudes. The respondents' reactions to target statements and their attitudes to the given matter were restricted by offering a set of fixed statements for respondents to choose from. The extremes of the seven-point scale represented bipolar concepts of the evaluation dimension. Using a scale of 1 to 4 , respondents expressed their inclination towards one of the pre-set extreme statements. The scale thus identified not only the respondents' attitudes, but also their intensity.

Our analysis of the data focused on statistical evaluation of the data firstly by means of a one-dimensional analysis based on the frequency distribution, calculation of point and interval estimates and testing hypotheses related to the frequency of the categories of individual variable values. Secondly, we performed a two-dimensional analysis of the dependence of two selected variables. The propositions were tested to establish whether there is a relationship between perception of the role lobbying plays in democracy and other selected statements. The goal of this comprehensive analysis of the several variables involved was to uncover any relations between the data structures and to interpret them. The information in the data file was retrieved using classic Pearson hypothesis 
testing. Pearson's correlation was applied. If the $\mathrm{p}-$ value calculated by means of the test was lower than the selected level of significance $\alpha=0.05$, the null hypothesis was rejected. Only resultant values of the Pearson's correlation coefficient with an absolute value of more than 0.3 were selected as being significant.

\section{Tested propositions}

A correlation analysis was used to review the survey output based on the processed data. The analysis was postulated so as to review the results based on the main structure of the questionnaire, which addressed dependence between lobbying activity carried out according to certain rules, the impact of lobbying on the facilitation of more competent political decision-making, information required for more competent decision-making based on lobbying, more efficient decision-making based on lobbying, negative perceptions of lobbying, self-regulation mechanisms for lobbying (ethical codex), regulation to limit lobbying, regulation to legitimize lobbying, and lobbying's positive influence on democracy. The parameters were tested at the 5 percent significance level. The results supporting the existence of dependency among the defined qualitative attributes are presented in the following section.

\section{Results}

In this section we present the results obtained from our primary survey. As can be seen in Table 1, most respondents perceive transparent lobbying positively when it is regulated and performed according to rules. Respondents stated that transparent lobbying mostly increases the legitimacy of decisions, increases the reliability and responsibility of politicians and officials, improves and cultivates good quality in government decisions, increases democratic principles and restricts corruption. The average values of the responses are very positive. Based on the four-point scale where 1 expresses strong agreement (positive perception) and 4 expresses strong disagreement (negative perception), the responses to questions related to democratic principles and transparent regulation are on average equal to 2 or below; the standard deviation values oscillate between 0.6 to 0.8 . On the other hand, non-transparent lobbying is perceived negatively and respondents also indicated that they largely somewhat disagree with limitations placed on lobbying (the mode and median values are in most of these cases equal to 3). Lobbying itself is not seen as a negative phenomenon.

Moreover, respondents indicated that lobbying without rules increases information asymmetry and uncertainty and increases "pragmatics" of information and potential risk of unilateral and pressure information. Therefore, it is possible to summarize that respondents believe regulated lobbying to be quite important for democratic principles.

There is a strong overall impression among the respondents (almost 93\% agree) that "acquaintances" play a major role in lobbying. Almost $90 \%$ of respondents agree that rules or regulations are needed in lobbying. Those rules should improve the legitimacy and transparency of lobbying, not limit lobbying activity. Lobbying is considered an important activity in democracy. 
Table 1 Perception of Questions Related to Transparent Lobbying

\begin{tabular}{|c|c|c|c|c|c|c|c|}
\hline Statement & $\begin{array}{l}\text { Agree } \\
\text { strong- } \\
\text { ly }\end{array}$ & $\begin{array}{l}\text { Some } \\
\text { what } \\
\text { agree }\end{array}$ & $\begin{array}{l}\text { some- } \\
\text { what } \\
\text { disagrees }\end{array}$ & $\begin{array}{l}\text { Disa- } \\
\text { gree } \\
\text { strongly }\end{array}$ & AVG & MOD & MED \\
\hline $\begin{array}{l}\text { It is a beneficial activity regardless of whether it is } \\
\text { performed according to certain rules }\end{array}$ & 4,35 & 8,70 & 47,83 & 39,13 & 3,27 & 3 & 3 \\
\hline $\begin{array}{l}\text { It is a beneficial activity only if it is performed ac- } \\
\text { cording to certain rules }\end{array}$ & 28,26 & 52,17 & 13,04 & 6,52 & 1,95 & 2 & 2 \\
\hline $\begin{array}{l}\text { It has a positive influence on developing democracy } \\
\text { in society (in terms of liberal democracy) }\end{array}$ & 6,52 & 50,00 & 34,78 & 8,70 & 2,51 & 2 & 2 \\
\hline $\begin{array}{l}\text { It facilitates more competent decision-making by } \\
\text { politicians }\end{array}$ & 4,35 & 41,30 & 39,13 & 15,22 & 2,68 & 2 & 3 \\
\hline $\begin{array}{l}\text { Competent decision-making does not require infor- } \\
\text { mation from lobbyists }\end{array}$ & 17,39 & 45,65 & 28,26 & 8,70 & 2,22 & 2 & 2 \\
\hline $\begin{array}{l}\text { Lobbying contributes to more efficient decision- } \\
\text { making }\end{array}$ & 8,89 & 44,44 & 37,78 & 8,89 & 2,55 & 2 & 2,5 \\
\hline $\begin{array}{l}\text { It should be limited (lobbying is a negative phenom- } \\
\text { enon) }\end{array}$ & 13,04 & 39,13 & 39,13 & 8,70 & 2,39 & 2 & 2 \\
\hline $\begin{array}{l}\text { Lobbying without rules increases information } \\
\text { asymmetry and uncertainty in information market }\end{array}$ & 35,56 & 53,33 & 8,89 & 2,22 & 1,78 & 2 & 2 \\
\hline $\begin{array}{l}\text { Lobbying without rules increases "pragmatics" of } \\
\text { information and potential risk of unilateral and } \\
\text { pressure information }\end{array}$ & 48,89 & 35,56 & 11,11 & 4,44 & 1,73 & 1 & 1,5 \\
\hline $\begin{array}{l}\text { Regulated lobbying does not reduce information } \\
\text { asymmetry and uncertainty }\end{array}$ & 6,67 & 42,22 & 40,00 & 11,11 & 2,50 & 2 & 2 \\
\hline "Acquaintances" play a major role in lobbying & 62,22 & 31,11 & 6,67 & 0,00 & 1,45 & 1 & 1 \\
\hline
\end{tabular}

Source: Primary questionnaire data; authors' processing.

We find statistically significant differences between the three observed groups of organisations (business, non-profit and other institutions) using the chi-square test. Non-profit organisations perceive transparency of lobbying measured on a scale statistically significantly better than respondents from businesses and public institutions.

In Table 2, the results show that lobbying regulations are perceived as very important and positive. Most respondents agree that lobbying should be regulated by law and according to ethical principles and codes. All the average values in response to questions regarding the separate legal regulation of lobbying are equal to 2 (partial agreement) or lower (on a scale where 1 is strong agreement and 4 is strong disagreement). More than $85 \%$ of respondents perceive that regulating lobbying leads to improved transparency and better decision-making. Furthermore, most respondents do not want such regulations to limit lobbying activity. They only suggest setting rules to ensure that lobbying is transparent. 
Table 2 Perception of Lobbying Regulation

Statement

\begin{tabular}{|c|c|c|c|c|c|c|}
\hline $\begin{array}{l}\text { Agree } \\
\text { strongly }\end{array}$ & $\begin{array}{l}\text { some } \\
\text { what } \\
\text { agree }\end{array}$ & $\begin{array}{l}\text { some- } \\
\text { what } \\
\text { disagree }\end{array}$ & $\begin{array}{l}\text { Disa- } \\
\text { gree } \\
\text { strongly }\end{array}$ & AVG & MOD & MED \\
\hline 26,09 & 47,83 & 23,91 & 2,17 & 1,98 & 2 & 2 \\
\hline 32,61 & 28,26 & 36,96 & 2,17 & 2,12 & 3 & 2 \\
\hline 44,44 & 42,22 & 8,89 & 4,44 & 1,73 & 2 & 2 \\
\hline 10,87 & 34,78 & 41,30 & 13,04 & 2,61 & 3 & 3 \\
\hline 68,89 & 24,44 & 6,67 & 0,00 & 1,38 & 1 & 1 \\
\hline 54,55 & 36,36 & 6,82 & 2,27 & 1,62 & 1 & 1 \\
\hline 17,78 & 48,89 & 20,00 & 13,33 & 2,30 & 2 & 2 \\
\hline 63,04 & 26,09 & 10,87 & 0,00 & 1,44 & 1 & 1 \\
\hline 11,11 & 8,89 & 64,44 & 15,56 & 2,93 & 3 & 3 \\
\hline 2,17 & 17,39 & 36,96 & 43,48 & 1,83 & 1 & 2 \\
\hline 50,00 & 45,65 & 4,35 & 0,00 & 1,51 & 1 & 1 \\
\hline 63,04 & 34,78 & 2,17 & 0,00 & 1,37 & 1 & 1 \\
\hline
\end{tabular}

Lobbying should be regulated by a separate law

Lobbying should be regulated by self-regulating mechanisms (e.g. a code of conduct)

Regulation of lobbying should be supplemented with more rules which generally improve transparency of decision-making and decision-making processes

The purpose of regulating lobbying is to limit lobbying activity

The purpose of regulating lobbying is to limit its eventual involvement with corruption

The purpose of regulating lobbying is to improve the transparency of decision-making in public services

The purpose of regulating lobbying is to legitimize lobbying as an activity

Unregulated lobbying enables the establishment of a corrupt environment

A general ethical code is sufficient for stipulating the rules of conduct for lobbyists and those they lobby

Ethical rules can be effectively enforced

Effective and adequate sanctions constitute an important part of the rules

Enforceability constitutes an important part of the rules

Source: Primary questionnaire data; authors' processing.

On the other hand, most respondents state that ethical codes alone are not sufficient as a means of regulating lobbying as they are not effectively enforced. Moreover, our results show that the regulations should include sanctions (more than $95 \%$ of respondents agree with this), and that enforceability plays an important role in regulating lobbying (97\% of respondents agree).

As results presented in Table 2 show, respondents believe that a major purpose of regulating lobbying is to limit its eventual involvement with corruption (more than $90 \%$ of respondents agree; the mode and median are equal to 1). Similar results were obtained in support of regulation that improves the transparency of lobbying legitimizes it. Almost $90 \%$ of respondents agree that unregulated lobbying fosters the establishment of a corrupt environment. 
Overall, our results suggest that respondents are supportive of regulated lobbying; they believe that regulations improve the transparency of lobbying activities and legitimize public decisions.

In addition to the above statistical analysis, we also tested the propositions stated in "Methods and Materials" to establish whether there is a relationship between perception of the role lobbying plays in democracy and other selected statements. To test these results, Pearson's correlation coefficient ( $\mathrm{r}$ ) was used. The first proposition tested was that where lobbying is perceived as having a positive influence on democracy this may be related to specific views on some of the other questionnaire statements. If there is such a connection, it would mean that the two statements affect each other: i.e. if support for regulated lobbying is related to a perception of lobbying having a positive effect on democracy, then the perception that lobbying has a positive effect on democracy will also be related to support for regulated lobbying (see Table 3).

\section{Table 3 Relations between Lobbying Practices}

Tested relation

Pearson's correlation

1: Rules of lobbying - lobbying positively influences democracy 0,358

2: Facilitation of competent decision-making of politicians - lobbying positively influences democracy

3: Requirements for information for decision-making - lobbying positively influences democracy

4: More efficient decision-making - lobbying positively influences democracy

5: Perception of lobbying as a negative phenomenon - lobbying positively influences democracy

6: Self-regulation mechanism of lobbying - lobbying positively influences democracy

7: Limitation of lobbying - lobbying positively influences democracy

8: The purpose of regulating lobbying is to legitimize lobbying as an activity - lobbying positively influences democracy

Source: Primary questionnaire data; authors ' processing.

As can be seen in Table 3, statistically significant correlations were found between the perception that lobbying has a positive influence on democracy and some practices related to lobbying as referred in Table 3 . The results are moderately strong. Based on these results, lobbying according to certain rules is positively related with lobbying having a perceived positive influence on democracy. That means regulated lobbying positively impacts democracy and vice versa, according to the perception of respondents who believe lobbying has a positive impact on democracy will also support regulation of lobbying. The same result was found with definition of requirements for information for decision-making, efficient decision-making, self-regulation mechanism and legitimization of lobbying. According to the perception of respondents who stated lobbying has a positive impact on democracy also support definition of requirements for information for decision-making. They also perceive that lobbying has a positive impact on 
efficient decision-making. Positive relation is supported between positive impact of lobbying on democracy and the purpose of regulating lobbying to legitimize lobbying as an activity. On the other hand, as expected, negative relationships were found between the perception that lobbying has a positive influence on democracy and the perception of lobbying as a negative phenomenon and between the perception that lobbying has a positive influence on democracy and the view that lobbying should be limited.

According to our respondents, transparent lobbying increases the legitimacy of public decisions, increases politicians' and officials' reliability and responsibility, improves and cultivates quality in government decisions, increases democratic principles and restricts corruption. On the other hand, non-transparent lobbying is perceived negatively. Lobbying is perceived as an important activity in democracy that should be conducted according to rules and regulations (ethical codes alone are perceived as insufficient). This may be because $93 \%$ of respondents have the impression that "acquaintances" play a major role in lobbying. The respondents indicated that regulation should ensure the transparency of lobbying, but not limit lobbying activity itself.

Regulating lobbying is perceived positively; the respondents indicated that regulations would improve the transparency of lobbying activities and legitimize the decisions based on lobbying.

Moreover, we found statistically significant differences between the responses given by representatives of businesses, non-profit and public institutions. Respondents from nonprofit organisations have a statistically significantly more positive perception of lobbying than respondents from business and public institutions.

\section{Discussion}

As stated in the theoretical section of this paper, the transparent lobbying was often discussed and perceptions of it rather less frequently. The current public economy can be characterised by a distinctly positive supply shock, at the core of which lies the rapid development of information and communication (Kruss et al., 2015; Urbancová et al., 2016). Such wide use of information brings ever increasing requirements with it in terms of our abilities to search for and process information, and places great emphasis on knowledge and its application in practice within our societies (Kloudová, 2012). Moreover, Wiszowaty (2006) states that the main purpose of lobbying transparency is that it extends help to lobbyists, and thus they are able to prepare for the legislative process at the government level in particular, which is usually the least accessible.

To compare the results of our questionnaire with previous research, we looked at a survey of Czech politicians in 2005 (with 362 respondents) that was undertaken by the local branch of a global PR and lobbying agency (McGrath, 2008). The most important results of that survey for our purposes are that most respondents believed that the public was poorly informed about the methods and utility of lobbying and that the public expected its politicians to reject lobbying. The results of our survey, in 2017, show that there has been either a significant shift from this lack of information towards a better informed public or the surveyed politicians in 2005 underestimated amount of information shared by public. 
McGrath (2008) collected information about the perception of lobbying in postcommunist countries. One of the surveys from 1999 covered almost 4000 firms in 25 countries undergoing transitions, and revealed that lobbying and corruption are closely negatively related phenomena; this means that it is rare to find corruption is rife in places where there is higher engagement in lobbying (Campos and Giovannoni, 2007). The same study also shows that respondents perceived transparency in lobbying very positively.

McGrath (2008) adds that surveys of companies from 2001 to 2004 revealed a slow increase in awareness of the importance of lobbying in the CEE nations. In 2001, $58 \%$ of firms questioned had never engaged in lobbying at the national level and $79 \%$ had never lobbied in Brussels. Between 2001 and 2004 the percentage of companies in the Czech Republic that saw lobbying as important rose from 61 to $84 \%$. The results of our survey in 2017 suggest that this percentage now oscillates around 90\%. Thus it seems that there has been a significant shift in the perception of lobbying in the Czech Republic after 2000 and now reaches slowly to maximum level.

As lobbying activity continues to increase (Transparency International, 2017), we are experiencing an ongoing debate about greater control of lobbying practices. Based on our results, it does appear that there is demand for new (or increasingly effective) mechanisms to regulate lobbying. We therefore suggest possible ways in which this could be achieved (assembled inter alia, on the basis of studies by Finel and Lord (1999), Striton and Lodge (2001), Bunting (2004), Fairbanks et al. (2007), Campos and Giovannoni (2007), and McGrath (2008)):

- Usually the most effective way is for lobbyists to cooperate within professional associations that are capable of representing their whole industry. Such groups do already exist, but they could be usefully developed.

- Lobbyists' professional groups should grow their membership base across all sectors as much as possible. They should also build up their internal structures so as to create and maintain a body of knowledge about the representation of their memberships' interests.

- We suggest that students, young people and business should enter into a productive dialogue with relevant academics to provide ongoing education in this area.

- Last but not least, lobbying should be promoted as actively as possible to disseminate the idea that lobbying is a legitimate and valuable activity in democratic political systems.

The entire lobbying process can be carried out without transparency and without rules, but rules and regulations reduce corrupt practices and thus lead to the maximisation of the principal's interests rather than personal interests. Our analysis presented in this paper extends the current knowledge on how lobbying activity is perceived by interest groups, and to what extent rules and regulations should be imposed on lobbying practices.

Our results confirm that transparent lobbying is seen as an integral part of democracy. More transparent lobbying is perceived as being connected with more competent, efficient and better-informed political decision-making. The respondents indicated that both self-regulation mechanisms (ethical codes for lobbyists) and regulations aiming at legitimizing lobbying would have a positive effect on democracy. 
Based on these results, we can conclude that lobbying is perceived as a positive phenomenon in democracy, and one that should not be limited. Transparent lobbying is perceived as having a positive impact on democracy. The overall perception of lobbying and lobbying transparency is increasingly positive, if we compare our results with those from similar studies made in the past. Czech organisational representatives now have a higher awareness of lobbying and its practices and can provide clear statements regarding lobbying regulations.

The limitations of this paper include the relatively limited sample of respondents. Organisations and thus respondents in the Czech Republic are not always familiar with lobbying, therefore a sample of 73 respondents from organisations can be described as sufficient. Nevertheless, the results can be applied only to the sample of respondents organisations and institutions questioned and operating in the Czech Republic. This article may be considered as a case study of how lobbying practices and transparency in lobbying are perceived in the surveyed organisations in the Czech Republic. Further research would be desirable to validate and extend our results.

Disclosure statement: No potential conflict of interest was reported by the authors.

\section{References}

BEAUMONT, E. (1999). Democracy and public administration reform linked. The Public Manager, 28(1): 47-50.

BELLVER, A. and D. KAUFMANN. (2005). Transparenting Transparency: Initial Empirics and Policy Applications. World Bank Policy Research Working Paper.

BENNEDSEN, M. and S. E. FELDMAN. (2002). Lobbying Legislatures. Journal of Political Economy, 110(4): 919-946. DOI: 10.1086/340775

BUNTING, R. (2004). The new peer review watchword. The CPA Journal, 74(10): 6-9.

CAMPOS, N. F., and F. GIOVANNONI. (2007). Lobbying, corruption and political influence. Public Choice, 131(1-2): 1-21. DOI: 10.1007/s11127-006-9102-4

COTTERRELL, R. (1999). Transparency, mass media, ideology and community. Cultural Values, 3(4): 414-426. DOI: 10.1080/14797589909367176

DONATH-BURSON-MARSTELLAR. (2005). A Guide to Effective Lobbying in the Czech Republic. Donath-Burson-Marstellar: Prague.

FAIRBANKS, J., K. D. PLOWMAN and B. L. RAWLINS. (2007). Transparency in government communication. Journal of Public Affairs, 7: 23-37. DOI: 10.1002/pa.245

FINEL, B. I., and K.M. LORD. (1999). The surprising logic of transparency. International Studies Quarterly, 43: 315-339.

FLORINI, A. (2004). Behind closed doors: governmental transparency gives way to secrecy. Harvard International Review, 26(1): 18-21.

FROST, A. (2003). Restoring faith in government: transparency reform in the United States and the European Union. European Public Law, 9(1): 87-104. 
FRYE, T. (2002). Capture or exchange? Business lobbying in Russia. Europe-Asia Studies, 54(7): 1017-1036. DOI: 10.1080/0966813022000017113

GARNETT, J. L. (1992). Communicating for Results in Government. Jossey-Bass Publishers: San Fransisco.

GOODMAN, M. B. (2002). Guest editorial. Corporate Communications, 7(4): 204-205.

GRØDELAND, A. (2006). Informality, corruption and public procurement in the Czech Republic, Slovenia, Bulgaria and Romania. In Informal Networks and Political Corruption in Post-Socialist Societies, KUSZNIR, J. (ed.). Koszalin Institute of Comparative European Studies: Koszalin, 25-36.

GRUNIG, J., and T. HUNT. (1984). Managing Public Relations. Holt, Rinehart and Winston: New York.

HEISE, J. A. (1985). Toward closing the confidence gap: an alternative approach to communication between public and government. Public Affairs Quarterly, 9(2): 196217.

HELLMAN, J. S., G. JONES, and D. KAUFMANN. (2000). "Seize the state, seize the day': state capture, corruption, and influence in transition. Policy Research Working Paper 2444. World Bank: Washington, DC.

KALNINŠ, V. (2005). Parliamentary Lobbying Between Civil Rights and Corruption: An Insight into Lobbying Practice in Latvia and Recommendations for the Saeima. Latvian Institute of International Affairs: Riga.

KLOUDOVÁ, K., et al. (2012). Kreativní ekonomika. Trendy, výzvy, přiležitost. Praha: Grada Publishing.

KRUSS, G., S. MCGRATH, I. H. PETERSEN, and M. GASTROW. (2015). Higher education and economic development: The importance of building technological capabilities. International Journal of Educational Development, 43: 22-31. DOI: 10.1016/j.ijedudev.2015.04.011

LABOUTKOVÁ, Š., and P. VYMĚTAL. (2017). Measures of Transparent Lobbying: How to Approach It and Evaluate It: A Preliminary Stage. In: Matějová, L. (ed.) Proceedings of the 21st International Conference Current Trends in Public Sector Research 2017. Brno: Masaryk University, pp. 50-57.

LABOUTKOVÁ, Š., and M. ŽÁK. (2016). Transparency of lobbying: A theoretical approach. Proceedings of the $14^{\text {th }}$ International Scientific Conference Economic Policy in the European Union Member Countries. Petrovice u Karviné: Silesian University in Opava, School of Business Administration in Karvina.

MCGRATH, C. (2008). The development and regulation of lobbying in the new member states of the European Union. Journal of Public Affairs, 8: 15-32. DOI: 10.1002/pa.284

MOE, T. M. (1984). The New Economics of Organization. American Journal of Political Science, 28(4): 739-777. 
OECD. (2006). Governance Arrangements to Ensure Transparency in Lobbying: Comparative Overview. Public Governance Committee, GOV/PGC/ETH (2006). Organisation for Economic Co-operation and Development: Paris.

PÉREZ-SOLÓRZANO BORRAGÁN, N. (2006). Post-communist interest politics: a research agenda. Perspectives on European Politics and Society, 7(2): 134-154. DOI: $\underline{10.1080 / 15705850600839868}$

PAVLÍK, M. (2013). Transparency in the Allocation of Municipal Grants for Sports and Voucher Systems in the Czech Republic. Review of Economic Perspectives Národohospodářrský obzor, 13(1): 43-57. DOI:10.2478/v10135-012-0015-5.

PUTNAM, R. D. (1995). Bowling alone: America's declining social capital. Journal of Democracy, 6(1): 65-78. DOI: 10.1353/jod.1995.0002

REDOANO, M. (2010). Does Centralization affect the Number and Size of Lobbies? Journal of Public Economic Theory, 12 (3): 407-435. DOI: 10.1111/j.14679779.2010.01459.x

REYNOLDS, M. (2005). Secretive lobbyists still wield influence. Prague Post, 7 September 2005.

SEVELLA, J. (2006). The state of Central European public affairs in Brussels. In Challenge and Response: Essays on Public Affairs and Transparency. SPENCER, T., and C. MCGRATH. (eds). Landmarks: Brussels; 89-94.

SCHLOZMAN, K. L., and J. T. TIERNEY. (1986). Organized Interests and American Democracy. New York: Harper \& Row.

SOPÓCI, J. (2001). Economic interest groups in Slovak politics in Nineties. Sociológia, 33(6): 535-548.

STOKER, K., and B. RAWLINS. (2004). Light and air hurt no one: The moral and practical imperative for transparency. Seventh Annual Interdisciplinary Public Relations Research Conference, Miami, Florida.

STRITON L., and M. LODGE. (2001). Transparency mechanisms: building publicness into public services. Journal of Law and Society, 28(4): 471-489. DOI: 10.1111/1467$\underline{6478.00199}$

STUBB, A. (2008). Report on the development of the framework for the activities of interest representatives (lobbyists) in the European institutions, (2007/2115(INI)), European Parliament, Committee on Constitutional Affairs.

SULliVAN, J. D., K. E. BETTCHER, and A. SHKOLNIKOV. (2006). Business associations, business climate, and economic growth: evidence from transition economies. Annual meeting of the International Society for New Institutional Economics.

SYKES, S. (2002). Talent, diversity and growing expectations. Journal of Communication Management, 7(1): 79-86. DOI: 10.1108/13632540310807278

TRANSPARENCY INTERNATIONAL (2017). Corruption Perceptions Index 2016. Retrieved May 14, 2017 from https://www.transparency.cz/wpcontent/uploads/Corruption-Perceptions-Index-2016.pdf 
URBANCOVÁ, H., L. VNOUČKOVÁ, and Š. LABOUTKOVÁ (2016). Knowledge Transfer in a Knowledge-Based Economy. E+M Economics and Management, 19(2): 73-86.

VISHWANATH, T. and D. KAUFMANN. (1999). Towards Transparency in Finance and Governance. Policy Research Working Paper. World Bank, Washington D.C.

WIESENTHAL, H. (1996). Organized interests in contemporary East Central Europe: theoretical perspectives and tentative hypotheses. In Parliaments and Organized Interests: The Second Steps, ÁGH, A., and G. ILONSZKI. (eds). Hungarian Centre for Democracy Studies: Budapest; 40-58.

WISZOWATY, M. M. (2006). Legal regulation of lobbying in new member states of the European Union. In Participation of Civil Society in New Modes of Governance, The Case of the New EU Member States. Part 2: Questions of Accountability. Research Centre for East European Studies: Bremen, 46-56. 